\title{
Micronutrient Content and Physiological Quality of Soybean Seeds
}

\author{
Geliandro Anhaia Rigo ${ }^{1}$, Luis Osmar Braga Schuch ${ }^{1}$, Rodrigo Lamaison de Vargas ${ }^{1}$, Willian Silva Barros ${ }^{1}$, \\ Vinícius Jardel Szareski ${ }^{1}$, Ivan Ricardo Carvalho ${ }^{1}$, Cristian Troyjack ${ }^{1}$, João Roberto Pimentel ${ }^{1}$, \\ Ruddy Alvaro Veliz Escalera ${ }^{1}$, Tiago Corazza da Rosa ${ }^{1}$, Velci Queiróz de Souza ${ }^{2}$, \\ Tiago Zanatta Aumonde ${ }^{1} \&$ Tiago Pedó $^{1}$ \\ ${ }^{1}$ Federal University of Pelotas, Capão do Leão, RS, Brazil \\ ${ }^{2}$ Universidade Federal do Pampa, Dom Pedrito, RS, Brazil \\ Correspondence: Vinícius Jardel Szareski, Federal University of Pelotas, Capão do Leão, RS, Brazil. E-mail: \\ viniciusszareski@gmail.com \\ Ivan Ricardo Carvalho, Federal University of Pelotas, Capão do Leão, RS, Brazil. E-mail: \\ carvalho.irc@gmail.com \\ Received: October 30, 2017 \\ Accepted: January 4, $2018 \quad$ Online Published: March 15, 2018 \\ doi:10.5539/jas.v10n4p223 \\ URL: https://doi.org/10.5539/jas.v10n4p223

\begin{abstract}
The aimed to correlate the micronutrients content in soybean seeds with their physiological potential. The work was developed in the Federal University of Pelotas, in the facilities of the Seed Science and Technology Graduate Program. The experimental design was randomized blocks in arranged in four replicates. The micronutrients measured were: $\mathrm{B}, \mathrm{Cu}, \mathrm{Fe}, \mathrm{Mn}, \mathrm{Mo}, \mathrm{Zn}, \mathrm{Al}$ and $\mathrm{Na}$. The magnitudes of micronutrients are dependent on the genetic constitutions of soybean cultivars. Higher variations are expressed for boron, copper, manganese, zinc, molybdenum, sodium and aluminum content, while iron is the most stable micronutrient in soybean seeds. Molybdenum and copper are characterized as determining micronutrients for physiological quality of soybean seeds.
\end{abstract}

Keywords: nutritional composition, minerals, interrelationships

\section{Introduction}

Soybean is one of the main crops grown in the word, it is a protein source for human and animal consumption (Kavalco et al., 2015). This crop is an important pillar of modern agriculture, which advances from north to south of Brazil, being base for a sustainable agribusiness (Carvalho et al., 2015). Among the species grown in Brazil, soybean stands out with the highest increment in the 2016/2017 growing season, being sown in 33.9 million hectares, with average yield of 3.4 tons per hectare and production of more than 114 million tons of grains (CONAB, 2017).

This quick growth in Brazil was boosted by the economic advantages for farmers, new cultivars, availability of technology, seeds of high quality and efficient treats (Szareski et al., 2016). The physiological quality of seeds is a summation of its attributes that indicate the ability of developing vital functions as germination, vigor and longevity (Peske et al., 2012). In this view, high quality seeds may result in increments of $35 \%$ in grain yield when compared to seeds of low physiological quality (Kolchinski et al., 2005; Schuch et al., 2009; Szareski et al., 2016).

The micronutrient content in the seeds is relevant for initial establishment of seedlings, where the nutrient fraction varies among species, cultivars and environmental conditions of the seed production field (Marcos Filho, 2015). The micronutrient deficiency, specially manganese and zinc, reduces the metabolic activity due to its high demand in physiological processes, being essential components for enzymatic activation, structural manutention and membranes integrity (Römheld \& Marschner, 1991; Teixeira et al., 2005). In this context, this work aimed to correlate the micronutrients content in soybean seeds with their physiological potential.

\section{Material and Methods}

This work was performed in the facilities of the Seed and Science Technology Graduation Program of the Federal University of Pelotas The experiment was carried out in a randomized block design, with treatments arranged in four replicates. 
It was used the seeds of cultivars BMX Apolo RR (12 lots), BMX Ativa RR (13 lots), BMX Energia RR (26 lots), BMX Força RR (24 lots), BMX Impacto RR (35 lots), BMX Magna RR (16 lots), BMX Turbo RR (44 lots), BMX Potência RR (82 lots) and NA 5909 RR (28 lots) produced in Northeast Rio Grande do Sul. Evaluations of plant tissue nutritional contents were obtained through the Laboratory of Chemical Analysis at the IBRA (Brazilian Institute of Analyzes) located in Sumaré, SP. The micronutrients measured were: Boron (B), Copper $(\mathrm{Cu})$, Iron ( $\mathrm{Fe})$, Manganese (Mn), Molybdenum (Mo), Zinc ( $\mathrm{Zn})$, Aluminum ( $\mathrm{Al}$ ) and Sodium (Na). The nutrients extraction occurred according to the methodology proposed by Malavolta (2006). The incineration method for digestion of B and Mo was used, where $200 \mathrm{mg}$ of each sample was transferred to a crucible and incinerated at $550^{\circ} \mathrm{C}$ for 3 hours, then cooled with addition of $10 \mathrm{ml}$ of $0.1 \mathrm{~N}$ of $\mathrm{HCl}$.

For an extraction of $\mathrm{Cu}, \mathrm{Fe}, \mathrm{Mn}, \mathrm{Zn}, \mathrm{Al}$, and $\mathrm{Na}$, the method of decomposition by nitric-perchloric digestion was used. The mass of 0.50 grams of dry matter was added with $9.0 \mathrm{~mL}$ of nitric-perchloric mixture in the proportion of 3.5:1 (v/v), with pre-digestion at room temperature for 12 hours. Sample digestion was carried out on a hotplate at $160{ }^{\circ} \mathrm{C}$, and then raising the temperature to $200{ }^{\circ} \mathrm{C}$ until the samples become a colorless extract. After cooling of the glass vials, around $2 \mathrm{~mL}$ of ultra-pure water was added, and the extract was transferred to a $50 \mathrm{~mL}$ volumetric flask. A read solution was homogenized and transferred to glass vials which remained standing for 12 hours for amorphous silica decantation.

Boron was determined by colorimetry of $\mathrm{H}$ azomethine with determination based on the formation of a colored complex by reaction of boric acid with $\mathrm{H}$ azomethine reagent. Copper, iron, manganese, zinc, molybdenum, sodium and aluminum (nitrous oxide) were directly determined on nitric-perchloric extracts by atomic absorption spectrophotometry using respective hollow cathode lamps. Copper determination was made with scaling expansion due to its low concentration in plants, compared to other cationic micronutrients. All micronutrients were expressed as $\mathrm{mg} \mathrm{kg}^{-1}$.

Seeds physiological quality was evaluated in the Seed Analysis Laboratory of the company Dimicron Química do Brasil Ltda., where the germination test was conducted with four sub-samples of 100 seeds per replicate for each treatment, seeded in rolls of Germitest paper moistened with an amount of water equivalent to 2.5 times the paper's dry mass. Seeds were kept in a germinator at $25^{\circ} \mathrm{C}$. The evaluations were carried out five and eight days after sowing, according to the Rules for Seed Analysis (Brasil, 2009), with results expressed as percentage of normal seedlings.

Accelerated aging (AA) was ca-rried out in a gerbox with metallic screen, being added $40 \mathrm{~mL}$ of distilled water, and on the screen, the seeds from each lot were evenly distributed in a single layer. After that, the boxes were allocated in a BOD incubator at $41^{\circ} \mathrm{C}$, remaining for 48 hours, then the germination test was performed (Marcos Filho et al., 1999).

Viability was verified by the tetrazolium test (PG), where each treatment was subdivided into four samples of 50 seeds, which were preconditioned on paper towels moistened at $30{ }^{\circ} \mathrm{C}$ and kept in a humid environment (germinator) for 16 hours. After this period, seeds were transferred to containers and immersed in $0.075 \%$ of tetrazolium salt solution, and kept in oven at $40{ }^{\circ} \mathrm{C}$ for four hours. After developing the stain, the seeds were washed in running water and evaluated according to criteria proposed by Costa et al. (2007). The weight of one thousand seeds (WTS) was determined by the measurement of eight replicates of 100 seeds, adjusting the values for weight of one thousand seeds (Brasil, 2009), with results in grams.

The data were submitted to analysis of variance at $5 \%$ of probability, verifying its assumptions. The characters which showed significance were submitted to complementary analyzes by Tukey test at $5 \%$ of probability, and then, linear correlation analysis was performed.

\section{Results and Discussion}

The analysis of variance revealed significance at $5 \%$ of probability for all characters. The linear correlation analysis (Table 1) presented associations between micronutrient contents of soybean seeds and physiological quality of the different cultivars. The boron content (B) is positively associated with germination (GER) for cultivars BMX Apolo RR and BMX Ativa RR, in contrast, the cultivar BMX Apolo RR expresses positive association with boron content, accelerated aging (AA) and vigor by tetrazolium test (Vtz).

A positive correlation was observed between boron (B) content and weight of one thousand seeds (WTS) for the cultivars BMX Apolo RR, BMX Ativa RR and BMX Força RR. Boron is characterized as an important micronutrient for plants, as it acts on the metabolism of carbohydrates, transport of sugars in membranes, synthesis of nucleic acids, phytohormones, walls formation and cell division (Sarsos et al., 2016; Zimmer et al., 2016). The copper content $(\mathrm{Cu})$ showed positive correlation with percentage of germination (GER), and 
accelerated aging (AA) only for the cultivar BMX Impacto RR. The content of this nutrient correlated positively with seeds viability verified by tetrazolium test (PG) for the cultivar BMX Impacto RR and NA5909 RR. The weight of one thousand seeds (WTS) revealed positive associations with copper content $(\mathrm{Cu})$ for cultivars BMX Apolo RR and BMX Energia RR. However, negative correlation was expressed between iron content (Fe) and percentage of germination (GER) for the cultivar BMX Magna RR. The cultivar BMX Apolo RR negatively associated viability (PG) with seed vigor by tetrazolium test (Vtz). The cultivar BMX Turbo RR presented inverse tendencies between iron content and weight of one thousand seeds (WTS).

The manganese content (Mn) of soybean seeds was positively associated with the weight of one thousand seeds (WTS) for the cultivar BMX Força RR, Influences of manganese were observed on seeds physiological quality, mainly regarding the lignin fraction (Marschner, 1995), which is one of the cellular wall substances that confers waterproofing (McDougal et al., 1996). It alsoacts on the capacity and speed of water absorption by the tegument, changes the amount of leached released to the external environment, being the lignin fraction inversely proportional to electric conductivity of the seeds (Panobianco et al., 1999; Dellagostin et al., 2016; Strobel et al., 2016).

There were positive correlations between zinc content ( $\mathrm{Zn})$, percentage of germination (GER), accelerated aging (AA), viability (PG) and vigor obtained by the tetrazolium test (VTz) for the cultivar BMX Impacto RR. For accelerated aging (AA), the cultivar BMX Magna RR positively correlated with zinc content (Table 1). Studies have affirmed that zinc seed treatment provided benefits for germination, physiological potential of seeds and initial establishment of canola plants (Pletsch et al., 2014). The sodium (Na) content in soybean seeds was positively correlated with germination (GER) and accelerated aging (AA) for the cultivar BMX Força RR. 
Table 1. Pearson's correlation between micronutrient contents in the seeds and the characters germination (Ger), accelerated aging (AA), viability by tetrazolium test (PG), vigor by tetrazolium test (VTz) and weight of one thousand seeds (WTS) in different soybean cultivars

\begin{tabular}{|c|c|c|c|c|c|c|c|c|c|c|}
\hline \multirow{2}{*}{ Cultivars } & \multicolumn{5}{|c|}{ B } & \multicolumn{5}{|c|}{$\mathrm{Cu}$} \\
\hline & Ger & $\mathrm{AA}$ & $\mathrm{PG}$ & $\mathrm{VTz}$ & WTS & Ger & $\mathrm{AA}$ & $\mathrm{PG}$ & VTz & WTS \\
\hline BMX Apolo RR & $0.96 * *$ & $0.99 * *$ & 0.14 & 0.36 & $0.98 * *$ & 0.66 & 0.62 & -0.32 & -0.09 & $0.96^{* *}$ \\
\hline BMX Ativa RR & $0.76^{*}$ & 0.28 & 0.06 & $0.85^{*}$ & $0.78^{*}$ & -0.3 & -0.17 & -0.53 & -0.48 & 0.09 \\
\hline BMX Energia RR & -0.54 & -0.67 & -0.15 & 0.03 & 0.2 & 0.31 & 0.39 & 0.28 & $.75 *$ & $0.74 *$ \\
\hline BMX Força RR & 0.05 & -0.14 & -0.44 & -0.41 & $0.72 *$ & 0.11 & 0.16 & 0.65 & 0.54 & 0.12 \\
\hline BMX Impacto RR & -0.45 & -0.4 & -0.49 & -0.47 & -0.61 & $0.94 * *$ & $0.86^{* *}$ & $0.92 * *$ & $0.93 * *$ & 0.33 \\
\hline BMX Magna RR & 0.15 & 0.31 & 0 & 0.05 & 0.03 & -0.54 & -0.55 & 0.46 & 0.6 & -0.14 \\
\hline NA 5909 RR & 0.6 & 0.13 & -0.49 & -0.68 & 0.58 & 0.59 & 0.18 & $0.70 *$ & $0.74^{*}$ & -0.23 \\
\hline BMX Potência RR & -0.58 & -0.47 & 0.02 & 0.27 & -0.54 & 0.57 & 0.8 & 0.4 & 0.48 & -0.47 \\
\hline BMX Turbo RR & -0.44 & -0.58 & -0.43 & -0.3 & -0.28 & 0.13 & -0.09 & -0.42 & -0.41 & -0.66 \\
\hline \multirow{2}{*}{ Cultivars } & \multicolumn{5}{|c|}{$\mathrm{Fe}$} & \multicolumn{5}{|c|}{ Mn } \\
\hline & Ger & $\mathrm{AA}$ & PG & $\mathrm{VTz}$ & WTS & Ger & $\mathrm{AA}$ & PG & $\mathrm{VTz}$ & WTS \\
\hline BMX Apolo RR & -0.39 & -0.08 & -1 & -0.97 & 0.04 & 0.54 & 0.59 & 0.66 & 0.82 & 0.61 \\
\hline BMX Ativa RR & 0.08 & 0.08 & 0.57 & -0.06 & -0.33 & -0.49 & -0.41 & -0.06 & -0.03 & 0.26 \\
\hline BMX Energia RR & 0.15 & 0.2 & -0.22 & 0.16 & -0.29 & 0.33 & 0.29 & -0.35 & -0.19 & 0.13 \\
\hline BMX Força RR & 0.02 & 0.04 & 0.2 & -0.06 & 0 & 0.25 & 0.06 & 0.1 & 0.07 & $0.89 * *$ \\
\hline BMX Impacto RR & -0.27 & -0.31 & -0.18 & -0.19 & -0.23 & -0.06 & -0.11 & 0.07 & 0.1 & 0.01 \\
\hline BMX Magna RR & -0.89 & -0.18 & 0.3 & 0.42 & 0.03 & -0.71 & -0.57 & 0.4 & 0.54 & 0 \\
\hline NA 5909 RR & 0.52 & 0.15 & 0.42 & 0.39 & 0.24 & 0.43 & 0.11 & 0.27 & 0.22 & 0.39 \\
\hline BMX Potência RR & 0.29 & 0.5 & 0.43 & 0.17 & 0.45 & 0.52 & 0.52 & 0.61 & 0.45 & -0.03 \\
\hline BMX Turbo RR & 0.21 & 0.1 & 0.25 & -0.26 & -0.75 & -0.29 & -0.2 & 0.59 & 0.6 & -0.48 \\
\hline \multirow{2}{*}{ Cultivars } & \multicolumn{5}{|c|}{$\mathrm{Zn}$} & \multicolumn{5}{|c|}{$\mathrm{Na}$} \\
\hline & Ger & $\mathrm{AA}$ & PG & $\mathrm{VTz}$ & WTS & Ger & $\mathrm{AA}$ & PG & VTz & WTS \\
\hline BMX Apolo RR & -0.68 & -0.41 & -0.64 & -0.59 & -0.3 & -0.43 & -0.7 & 0.67 & 0.48 & -0.58 \\
\hline BMX Ativa RR & -0.37 & 0.51 & 0.08 & -0.61 & 0.53 & 0.42 & 0.37 & 0.4 & 0.36 & -0.17 \\
\hline BMX Energia RR & -0.36 & -0.34 & -0.06 & -0.03 & -0.12 & -0.06 & 0.01 & 0.08 & 0.47 & -0.47 \\
\hline BMX Força RR & 0.36 & 0.26 & -0.14 & -0.3 & 0.33 & $0.82 *$ & $0.72 *$ & 0.37 & 0.32 & 0.45 \\
\hline BMX Impacto RR & $0.8^{* *}$ & $0.87 * *$ & $0.72 *$ & $0.72 *$ & 0.25 & -0.18 & -0.26 & -0.14 & -0.14 & -0.55 \\
\hline BMX Magna RR & 0.31 & $0.76^{*}$ & 0.53 & 0.67 & 0.18 & -0.16 & 0.49 & -0.33 & -0.4 & 0.3 \\
\hline NA 5909 RR & -0.22 & -0.35 & -0.3 & -0.34 & -0.22 & 0 & -0.47 & -0.27 & -0.47 & 0.24 \\
\hline BMX Potência RR & -0.25 & -0.51 & -0.43 & -0.49 & 0.19 & 0.28 & 0.49 & $0.91 *$ & 0.55 & -0.07 \\
\hline BMX Turbo RR & -0.2 & -0.38 & -0.52 & -0.53 & 0.01 & -0.25 & -0.4 & -0.19 & -0.17 & 0.46 \\
\hline \multirow{2}{*}{ Cultivars } & \multicolumn{5}{|c|}{ Al } & \multicolumn{5}{|c|}{ Mo } \\
\hline & Ger & $\mathrm{AA}$ & PG & $\mathrm{VTz}$ & WTS & Ger & $\mathrm{AA}$ & PG & $\mathrm{VTz}$ & WTS \\
\hline BMX Apolo RR & 0.33 & 0.61 & -0.75 & -0.57 & 0.5 & $0.98^{* *}$ & $0.98 * *$ & 0.23 & 0.44 & $0.96^{* *}$ \\
\hline BMX Ativa RR & -0.45 & 0.08 & -0.45 & -0.55 & 0.15 & 0.36 & -0.48 & -0.33 & 0.21 & -0.5 \\
\hline BMX Energia RR & 0.34 & 0.43 & 0.2 & 0.62 & 0.43 & -0.29 & -0.33 & 0.28 & -0.06 & 0.37 \\
\hline BMX Força RR & -0.59 & -0.59 & -0.25 & -0.15 & -0.1 & 0.48 & 0.36 & 0.13 & 0.22 & 0.48 \\
\hline BMX Impacto RR & -0.91 & -0.95 & -0.7 & -0.73 & -0.01 & 0.51 & 0.48 & 0.53 & 0.58 & 0.1 \\
\hline BMX Magna RR & -0.1 & 0.28 & -0.29 & -0.39 & 0.26 & 0.51 & $0.88 * *$ & 0.47 & 0.3 & 0.1 \\
\hline NA 5909 RR & -0.29 & 0.24 & -0.35 & -0.55 & $0.78^{*}$ & 0.11 & 0.15 & $0.74 *$ & 0.51 & $0.80 *$ \\
\hline BMX Potência RR & -0.31 & -0.21 & 0.11 & -0.17 & 0.36 & 0.52 & 0.72 & 0.33 & 0.55 & 0.51 \\
\hline BMX Turbo RR & 0.08 & 0.01 & -0.2 & -0.17 & -0.77 & 0.26 & 0.07 & 0.74 & $0.74 *$ & 0.19 \\
\hline
\end{tabular}

Note. ${ }^{* *}$ significant at $1 \%, *$ significant at $5 \%$.

Negative association was verified between aluminum content (Al) and percentage of germinated soybean (GER), accelerated aging (AA), viability (PG) and vigor bythe tetrazolium test (Vtz) for the cultivar BMX Impacto RR. 
Negative relationship between aluminum content (Al) and weight of one thousand seeds (WTS) was verified for the cultivar BMX Turbo RR. Molybdenum (Mo) content was positively correlated with percentage of germination (GER) for cultivar BMX Apolo RR, accelerated aging (AA) with cultivars BMX Apolo RR, BMX Magna RR and BMXPotência RR. Molybdenum is positively associated with viability obtained by the tetrazolium (PG) test for cultivars NA5909 RR, and BMX Turbo RR, this nutrient also correlates with weight of one thousand seeds for cultivars BMX Apolo RR and NA5909 RR.

The presence of molybdenum in the seed influences the percentage of germinated seeds and vigor, the increase of this nutrient concentration is directly proportional to the increase of seeds physiological potential (Leite et al., 2009; Pelegrin et al., 2016; Meira et al., 2016). Research evidences the beneficial effects of molybdenum on physiological quality of maize (Tanner, 1979). The increment of molybdenum in bean seeds benefits nodulation and nitrogen storage in the seeds (Brodricket et al., 1992). Higher proportions of molybdenum applied to soybean seeds or foliar area did not influence the physiological quality of seeds produced, grain yield and weight of a thousand seeds (Possenti \& Villela, 2010; Ferreira, 2001).

In general, micronutrients which positively correlate with, at least, one analyzed character, were: molybdenum (Mo) in $55.5 \%$ of the cultivars, copper $(\mathrm{Cu})$ in $44.4 \%$ of the cultivars, boron (B) in $33.3 \%$ of cultivars, zinc ( $\mathrm{Zn}$ ) in $22.2 \%$ of the cultivars, sodium (Na) in $22.2 \%$ of the cultivars, and manganese $(\mathrm{Mn})$ in $11.1 \%$ of the cultivars. However, the increase of iron (Fe) and aluminum (Al) levels negatively contributed with seeds physiological quality, presenting negative correlation with $22.2 \%$ of the cultivars (Table 2).

The cultivars BMX Apolo RR, BMX Energia RR, BMX Magna RR, BMX Potência RR, NA 5909 RR were superior, however, BMX Turbo RR expressed inferiority (Table 2) for boron (B) content. Frequently, it is a scarce micronutrient in Brazilian soils, as high boron content in the seeds influences physiological activities, enzymatic actions, cell division, cell wall formation, nucleic acid synthesis, phytohormones, carbohydrates and the transport of sugars through membranes (Ferreira \& Cruz, 1991; Soares et al., 2008; Follmann et al., 2016).

The highest concentration of copper $(\mathrm{Cu})$ was expressed through cultivars BMX Impacto RR, BMX Ativa RR and NA 5909 RR. The lowest copper content was presented through cultivars BMX Força RR and BMX Turbo $\mathrm{RR}$ (Table 2). Copper is characterized as a vital component for enzymes being, present in chloroplasts (Ferreira \& Cruz, 1991; Ferrari et al., 2016).

Iron content $(\mathrm{Fe})$ was higher for the cultivar BMX Impacto RR, with lower effects for the cultivar BMX Potência RR (Tables 1 and 2). Regarding manganese content (Mn), superiority was evidenced for cultivars BMX Apolo RR, NA 5909 RR and BMX Turbo RR (Table 2). Zinc content (Zn) revealed superiority for the cultivar BMX Impacto RR, studies define that zinc acts as activator of several enzymes and component of cellular structures (Ferreira \& Cruz, 1991). Plants grown under zinc deficiency produce seeds with low concentrations of this nutrient, less vigorous seedlings and lower grain yield (Genc et al., 2000; Nardino et al., 2016).

Table 2. Means of the micronutrients boron (B) copper ( $\mathrm{Cu}$ ), iron (Fe), Manganese (Mn), zinc ( $\mathrm{Zn})$, molybdenum $(\mathrm{Mo})$ and the elements aluminum (Al), and sodium ( $\mathrm{Na}$ )present in seeds of nine soybean cultivars

\begin{tabular}{|c|c|c|c|c|c|c|c|c|}
\hline Cultivars & $\mathrm{B}$ & $\mathrm{Cu}$ & $\mathrm{Fe}$ & $\mathrm{Mn}$ & $\mathrm{Zn}$ & Mo & $\mathrm{Na}$ & $\mathrm{Al}$ \\
\hline & \multicolumn{8}{|c|}{ 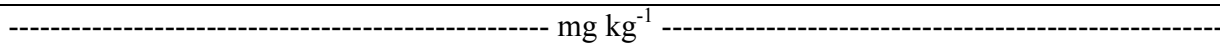 } \\
\hline BMX Apolo RR & $35.47 \mathrm{~A}$ & $12.66 \mathrm{BC}$ & $88.53 \mathrm{~A}$ & $33.33 \mathrm{~A}$ & $39.91 \mathrm{~B}$ & $4.02 \mathrm{AB}$ & $20.50 \mathrm{~B}$ & $20.00 \mathrm{C}$ \\
\hline BMX Ativa RR & $30.24 \mathrm{ABC}$ & $13.42 \mathrm{AB}$ & $100.74 \mathrm{~A}$ & $26.85 \mathrm{~B}$ & $40.07 \mathrm{~B}$ & $6.37 \mathrm{~A}$ & $19.46 \mathrm{~B}$ & $37.78 \mathrm{BC}$ \\
\hline BMX Energia RR & $28.97 \mathrm{BC}$ & $10.76 \mathrm{CD}$ & $93.47 \mathrm{~A}$ & $26.78 \mathrm{~B}$ & $38.5 \mathrm{~B}$ & 4.46 AB & $17.75 \mathrm{~B}$ & $54.29 \mathrm{BC}$ \\
\hline BMX Força RR & $34.91 \mathrm{AB}$ & $8.59 \mathrm{D}$ & $90.13 \mathrm{~A}$ & $26.53 \mathrm{~B}$ & $39.76 \mathrm{~B}$ & $3.92 \mathrm{AB}$ & $23.80 \mathrm{AB}$ & $15.00 \mathrm{C}$ \\
\hline BMX Impacto RR & $32.14 \mathrm{ABC}$ & $15.33 \mathrm{~A}$ & $113.33 \mathrm{~A}$ & $26.66 \mathrm{~B}$ & $50.33 \mathrm{~A}$ & $2.76 \mathrm{~B}$ & $37.66 \mathrm{~A}$ & $16.67 \mathrm{C}$ \\
\hline BMX Magna RR & $26.66 \mathrm{C}$ & $12.70 \mathrm{BC}$ & $102.50 \mathrm{~A}$ & $25.18 \mathrm{~B}$ & $40.15 \mathrm{~B}$ & $3.44 \mathrm{~B}$ & $28.14 \mathrm{AB}$ & $93.3 \mathrm{AB}$ \\
\hline BMX Potência RR & $25.92 \mathrm{C}$ & $10.72 \mathrm{CD}$ & $87.57 \mathrm{~A}$ & $26.48 \mathrm{~B}$ & $40.52 \mathrm{~B}$ & $4.40 \mathrm{AB}$ & $25.56 \mathrm{AB}$ & $37.11 \mathrm{BC}$ \\
\hline BMX Turbo RR & $16.55 \mathrm{D}$ & $9.80 \mathrm{D}$ & $104.72 \mathrm{~A}$ & $28.40 \mathrm{AB}$ & $36.68 \mathrm{~B}$ & $2.94 \mathrm{~B}$ & $26.09 \mathrm{AB}$ & $35.06 \mathrm{BC}$ \\
\hline NA 5909 RR & $26.83 \mathrm{C}$ & $13.07 \mathrm{AB}$ & $99.46 \mathrm{~A}$ & $30.00 \mathrm{AB}$ & $39.16 \mathrm{~B}$ & $2.40 \mathrm{~B}$ & $30.71 \mathrm{AB}$ & $116.61 \mathrm{~A}$ \\
\hline C.V. $(\%)$ & 20.61 & 16.89 & 36.20 & 17.21 & 16.45 & 53.88 & 50.05 & 91.07 \\
\hline
\end{tabular}

"Means followed by the same capitalized letter in the column do not differ by the Tukey test $(\mathrm{p} \leq 0.05)$.

The content of molybdenum (Mo) was higher for the cultivar BMX Ativa RR, with lower effects for cultivar NA 5909 RR. Molybdenum takes part in nutrient absorption, acting as an integrant cofactor of the enzymes 
nitrogenase, nitrate reductase and sulfate oxidase, with function of electron carrying (Lantmann, 2002; Broch \& Ranno, 2005; Grassi Filho, 2006). Soybean seeds enriched with molybdenum increase translocation of nutrients present throughout the plant to seeds (Milani et al., 2010). The sodium content (Na) was superior for the cultivars BMX Impacto RR, NA 5909 RR, BMX Magna RR, BMX Turbo RR, BMX Potência RR and BMX Força RR.

\section{Conclusion}

The magnitudes of micronutrients are dependent on the genetic constitutions of soybean cultivars. Higher variations are expressed for boron, copper, manganese, zinc, molybdenum, sodium and aluminum content, while iron is the most stable micronutrient in soybean seeds. Molybdenum and copper are characterized as determining micronutrients for physiological quality of soybean seeds.

\section{References}

Brasil. (2009). Ministry of Agriculture, Livestock and Food Supply. Rules for seed analysis (p. 395). Ministry of Agriculture, Livestock and Food Supply, Secretaria de Defesa Agropecuária. Brasília, DF: Mapa/ACS.

Broch, D. L., \& Ranno, S. K. (2005). Efeito da aplicação de molibidenio e cobalto na produtividade de soja na safra 2004/2005. In E. P. Borges (Ed.), Tecnologia e produção: Soja/milho 2005/2006 (Vol. 11, pp. 59-170). Maracaju: Fundação MS.

Brodrick, S. J., Sakala, M. K., \& Giller, K. E. (1992). Molybdenum reserves of seed, and growth and N 2 fixation by Phaseolus vulgaris L. Biology and Fertility of Soils, 13(1), 39-44. https://doi.org/10.1007/ BF00337236

Carvalho, I. R., Souza, V. Q., Nardino, M., Follmann, D. N., Demari, G., Schmidt, D., ... Olivoto, T. (2015). Effects of fungiciddes on determined habit soybean genotypes. Revista Sodebras, 10, 30-34.

CONAB. (2017). Companhia Nacional de Abastecimento. Acompanhamento da Safra Basileira de grãos, Primeiro levantamento (Vol. 4, No. 1, p.118).

Costa, N. P., França Neto, J. B., Krzyzanowski, F. C., \& Henning, A. A. (2007). Metodologia alternativa do teste de tetrazólio em sementes de soja. Circular Técnica, 39, 8.

Dellagostin, S. M., Bernardi, D., Nobrega, L. H. P., Dellagostin, D. M., Carvalho, I. R., Demari, G. H., ... Zimmer, P. D. (2016). Physiological parameters applied to the soybean seed storage techniques. International Journal of Current Research, 8, 41523-41527.

Dos Santos Neto, J. A., Fontes, R. L. F., Neves, J. C. L., Fontes, M. P. F., De Faria, A. F., \& Santos, H. S. N. (2015). Rates of boron recovered by different extractants from soils of Bahia and Minas Gerais, Brazil, with and without liming. Revista Brasileira de Ciência do Solo, 39(4), 1121-1126. https://doi.org/10.1590/ 01000683rbcs20140669

Ferrari, M., Pelegrin, A. J., Nardino, M., Carvalho, I. R., Szareski, V. J., Olivoto, T., ... Souza, V. Q. (2016) Evaluation of soybeans genotypes in field environments of Rio Grande do Sul state, Brazil. International Journal of Current Research, 8, 38383-38392.

Ferreira, A. C. de B. (2001). Nutrition and productivity of bean plants as a function of seed molybdenum contents and its foliar application (p. 80, Doctorate Thesis, Viçosa, UFV).

Ferreira, M. E., \& Cruz, M. C. P. (1991). Micronutrientes na agricultura (p. 734). Piracicaba: Potafós/CNPq.

Follmann, D. N., Souza, V. Q., Cargnelutti Filho, A., Nardino, M., Carvalho, I. R., Demari, G. H., ... Meier, C. (2016). Agronomic performance and stability of soybean cultivars in not preferred time. International Journal of Current Research, 8, 37665-37670.

Genc, Y., Mcdonal, G. K., \& Graham, R. (2000). Effect of seed content on early growth of barley (Hordeum vulgare L.) under low and adequade soil zinc supply. Australian Journal of Agricultural Research, 51(1), p.37-45. https://doi.org/10.1071/AR99045

Grassi Filho, H. (2006). Molibdênio nas plantas. Universidade Estadual Paulista, Faculdade de Ciências Agronômicas, Departamento de Recursos Naturais, Área de Ciência do Solo.

Kavalco, S. A. F., Souza, V. Q., Follmann, D. N., Carvalho, I. R., Nardino, M., \& Demari, G. H. (2015). Development if soybeans with hormones applications in different crop densities. Brasilian Journal of Sustainable Agriculture, 4, 1-10. 
Kolchinski, E. M., Schuch, L., \& Peske, S. T. (2005). Seeds vigor and intra-specific compettion in soybean. Ciência. Rural, 35, 1248-1256. https://doi.org/10.1590/S0103-84782005000600004

Lantmann, A. F. (2002). Nutrição e produtividade da soja com molibdênio e cobalto. Artigos Embrapa, Coletânea Rumos \& Debates.

Leite, U. T., Araújo, G. A. D. de A., De Miranda, G. V., Vieira, R. F., \& Pires, A. A. (2009). Effect of Molybdenum Contenton Physiological Quality of Bean Seeds: Cultivars Novo Jaloand Meia Noite. Revista Ceres, 56(2), 225-231.

Malavolta, E. (2006). Manual de nutrição de plantas (p. 631). São Paulo: Agronômica Ceres.

Marcos Filho, J. (2015). Fisiologia de Sementes de Plantas Cultivadas (2nd ed., p. 660). Abrates, Londrina, PR, Brasil.

Marcos Filho, J., Krzyzanowski, F., \& Vieira, R. D. (1999). Teste de envelhecimento acelerado. In J. B. França Neto (Ed.), Vigor de sementes: Conceitos e testes (Chap. 3, pp. 1-24). Londrina: Abrates.

Marschner, H. (1995). Mineral nutriation of higher plants (2nd ed., p. 889). Academic Press, San Diego.

McDougal, L. G. J., Morrison, I. M., Stewart, D., \& Hillman, J. R. (1996). Plant cell walls as dietary fibre: range, structure, processing and function. Journal Science Food Agriculture, 70(2), 133-150. https://doi.org/ 10.1002/(SICI)1097-0010(199602)70:2\%3C133::AID-JSFA495\%3E3.0.CO;2-4

Meira, D., Carvalho, I. R., Nardino, M., Follmann, D. N., Pelegrin, A. J., Szareski, V. J., ... Souza, V. Q. (2016). Path analysis and dissimilarity in soybean with indeterminate habit. International Journal of Current Research, 8, 39568-39573.

Milani, G. L., Oliveira, J. A., Pereira, E. M., Carvalho, B. O., Oliveira, G. E., \& Costa, R. R. (2010). Leaf application of molybdenum during soybean seed maturation. Ciência e Agrotecnologia, 4(34), 810-816. https://doi.org/10.1590/S1413-70542010000400003

Nardino, M., Carvalho, I. R., Demari, G. H., Pelissari, G., Pelegrin, A. J., Ferrari, M., ... Souza, V. Q. (2016). Components of variance, linear and canonical correlation soybean cultivars. Australian Journal of Basic and Applied Sciences, 10, 202-208.

Panobianco, M., Vieira, R. D., Krzyzanowski, F. C., \& França Neto, J. B. F. (1999). Electrical conductivity of soybean seed and correlation with seed coat lignin content. Seed Science and Technology, 27(3), 945-949.

Pelegrin, A. J., Carvalho, I. R., Nardino, M., Ferrari, M., Szareski, V. J., Belle, R., ... Souza, V. Q. (2016). Performance of resistant soybean to Asian rust in different environments in RS. International Journal of Current Research, 8, 38398-38401.

Peske, S. T., Villela, F. A., \& Meneghello, G. E. (2012). Sementes: Fundamentos Científicos e Tecnológicos (3rd ed., p. 573). Pelotas: Ed. Universitária.

Pletsch, A., Silva, V. N., \& Beutler, A. N. (2014). Treatment of canola seeds with zinc. Revista de Ciências Agrárias, 37(2), 241-247.

Possenti, J. C., \& Villela, F. A. (2010). The effect of molybdenum applied by foliar spraying and seed treatment on the physiological potential and productivity of soybean seeds. Revista Brasileira de Sementes, 32(4), 143-150. https://doi.org/10.1590/S0101-31222010000400016

Römheld, V., \& Marschner, H. (1991). Functions of micronutrients in plans. In J. J. Mortvedt (Ed.), Micronutrientsin Agriculture (pp. 297-328). Madison: Soil Science Society of America.

Schuch, L. O. B., Kolchinski, E. M., \& Finatto, J. A. (2009). Seed physiological quality and individual plants performance in soybean. Revista Brasileira de Sementes, 31(1), 144-149. https://doi.org/10.1590/S010131222009000100016

Soares, M. R., Casagrande, J. C., \& Alleoni, L. R. F. (2008). Boron adsorption in acric soils as a function of pH variation. Revista Brasileira de Ciência do Solo, 32(1), 111-120. https://doi.org/10.1590/S0100-068320 08000100011

Szareski, V. J., Carvalho, I. R., Nardino, M., Demari, G. H., Bahry, C. A., Kehl, K., ... Aumonde, T. Z. (2016). Phenotype stability of soybean genotypes for characters related to the physiological quality of seeds produced under different environmental conditions. Australian Journal of Basic and Applied Sciences, $10(15), 279-289$. 
Szareski, V. J., Carvalho, I. R., Nardino, M., Pelegrin, A. J., Ferrari, M., Gaviraghi, R., ... Souza, V. Q. (2016). Competition of soybean genotypes cultivated in lowlands of Rio Grande do Sul, Brazil. International Journal of Current Research, 8, 39714-39718.

Szareski, V. J., Zanatta, E., Koch, F., Aisenberg, G. R., Demari, G. H., Kehl, K., ... Aumonde, T. Z. (2016). Pre-harvest desiccation and seed production in soybean crops. International Journal of Current Research, 8 , 41534-41537.

Tanner, P. D. (1979). The effect of molybdenum on maize seed qualit. Journal Agriculture Research, 17, 125-129.

Teixeira, I. R., Borém, A., Araújo, G. A. A., \& Andrade, M. J. B. (2005). Nutrient contents and physiological quality of common bean seeds in response to leaf fertilization with manganese and zinc. Bragantia, 64(1), 83-88. https://doi.org/10.1590/S0006-87052005000100009

Zimmer, G., Koch, F., Carvalho, I. R., Szareski, V. J., Demari, G. H., Nardino, M., ... Pedo, T. (2016). Seed quality and initial performance of seedlings of soybean produced off-season in Rio Grande do Sul, Brazil. International Journal of Current Research, 8, 40325-40329.

\section{Copyrights}

Copyright for this article is retained by the author(s), with first publication rights granted to the journal.

This is an open-access article distributed under the terms and conditions of the Creative Commons Attribution license (http://creativecommons.org/licenses/by/4.0/). 